\title{
Bronchial responsiveness and lung function in infants with lower respiratory tract illness over the first six months of life
}

\author{
Jane R Clarke, Amanda Reese, Michael Silverman
}

\begin{abstract}
The aim of this study was to determine whether increased bronchial responsiveness to histamine is associated with lower respiratory tract illness (one or more episodes of wheeze or cough, or both) in infancy.

Fifty four normal newborn infants who had at least one atopic parent were recruited. At a median age of 6.5 months, 45 infants, 23 with a history of lower respiratory tract illness, and 22 without, underwent pulmonary function testing during a symptom free period. The maximum flow at functional residual capacity (VmaxFRC) was calculated from partial forced expiratory flow volume curves using the squeeze technique. Bronchial responsiveness to increasing doses of histamine was assessed by determining the provoking concentration which caused a $30 \%$ decrease in VmaxFRC $\left(\mathbf{P C}_{\mathbf{3 0}}\right)$.

The length adjusted VmaxFRC was lower for symptomatic infants before the challenge (median $125 \mathrm{ml} / \mathrm{s} ; 95 \%$ confidence intervals (CI) 85 to $164 \mathrm{ml} / \mathrm{s}$ ) compared with control infants (median $215 \mathrm{ml} / \mathrm{s} ; 95 \%$ CI 159 to 298 $\mathrm{ml} / \mathrm{s}$ ). There was no significant difference in $\mathbf{P C}_{30}$ between symptomatic infants (median $10.3 \mathrm{~g} / 1 ; 95 \% \mathrm{CI} 2.8$ to $23.8 \mathrm{~g} / \mathrm{l}$ ) and control infants (median $16.5 \mathrm{~g} / 1 ; 95 \%$ CI 2.4 to 27.9 g/l).
\end{abstract}

Bronchial responsiveness to histamine can be shown in most infants early in life and is independent of lower respiratory tract symptoms including wheezing.

\section{(Arch Dis Child 1992;67:1454-8)}

In groups of schoolchildren and adults there is an association between increased bronchial responsiveness and asthma, ${ }^{1-4}$ though in individual subjects variations in bronchial responsiveness correlate poorly with the clinical manifestations of asthma ${ }^{5-7}$ and with airway calibre at the time of testing. ${ }^{89}$ Bronchial responsiveness has been shown in infancy in recurrently wheezy subjects ${ }^{10} 11$ and in small groups of normal infants. ${ }^{12-14}$

Until recently little was known about the relation of bronchial responsiveness to wheezing in infancy. In one small study of recurrently wheezy infants it was shown that, in contrast with older subjects, bronchial responsiveness in infancy is independent of wheezing, but may be dependent on airway calibre. ${ }^{15}$

The aim of this study was to determine whether the airways of infants with lower respiratory tract illness (one or more episodes of wheeze or cough, or both) were more responsive to histamine than those of asymptomatic control subjects.

\section{Subjects and methods}

SUBJECTS

All 45 infants in this study were recruited in the neonatal period from Hammersmith Hospital or Queen Charlotte's and Chelsea Hospital, and were followed up as part of a cohort study. Of the 54 subjects who had originally been recruited, two had moved away from the area by the age of 6 months and seven no longer wished to take part in lung function tests. All members of the cohort had at least one atopic parent, but had otherwise been normal healthy term infants. Infants were classified according to the presence or absence of one or more episodes of cough or wheezing, or both (henceforth referred to as lower respiratory tract illness). Parents were interviewed and details of any recurrent cough or wheezing, or both, since birth were recorded, in addition to a detailed family history including smoking.

At the time of study at the age of 6 months, all infants had been free of respiratory symptoms for at least two weeks. None was receiving any drugs known to affect bronchial responsiveness. Infants were studied after sedation with chloral hydrate $(100 \mathrm{mg} / \mathrm{kg})$ or the equivalent dose of triclofos sodium $(167 \mathrm{mg} / \mathrm{kg})$. The study was approved by the hospital's ethics committee and parental consent was always obtained. Parents generally stayed in the laboratory during studies.

\section{LUNG FUNCTION}

Partial expiratory flow volume curves were obtained using the squeeze technique by rapidly inflating a snugly fitting, polythene thoracoabdominal jacket (medical engineering department, Royal Postgraduate Medical School, Hammersmith Hospital, London), with the arms enclosed, at the end of tidal inspiration to induce a forced expiration. ${ }^{16} 17$ The jacket inflation pressure was measured with a pressure transducer (Validyne MP45). From occlusion tests at the end of inspiration the static pressure transmission to the pleural space with this jacket is $56-80 \%$ of the applied pressure. ${ }^{18}$ Flow was recorded with a low resistance screen pneumotachograph (medical engineering department, Royal Postgraduate Medical School) and facemask (Rendell-Baker Soucek, size 1, Ambu International), connected to a pressure transducer (Validyne MP45). A rim of silicone putty (Carters) was applied around the
Correspondence to: Dr Silverman.

Accepted 24 July 1992 
mouth and nose and to the facemask to provide an airtight seal. The flow signal was electronically integrated with respect to time to give the volume. All signals were digitised $(100 \mathrm{~Hz})$ and stored on a computer (Compaq deskpro 386/ 20e). Partial expiratory flow volume curves were constructed by computer and analysed (RASP Software, Physiologic Ltd) to determine the maximum flow at a lung volume corresponding to the functional residual capacity (VmaxFRC). ${ }^{19}$ During baseline measurements the jacket pressure was increased from $25 \mathrm{~cm}$ $\mathrm{H}_{2} \mathrm{O}$ by increments of $5 \mathrm{~cm} \mathrm{H}_{2} \mathrm{O}$ until flow limitation had been achieved, as shown by the maximum flow at functional residual capacity, or until the maximum jacket pressure of $80 \mathrm{~cm}$ $\mathrm{H}_{2} \mathrm{O}$ had been achieved. A mean baseline value of $\dot{V} \operatorname{maxFRC}$ was derived from eight to 10 baseline measurements made at the optimal jacket pressure. Thereafter the same jacket pressure was used throughout the challenge test procedure.

The shape of the baseline partial expiratory flow volume curves was described qualitatively for each subject, as either concave or convex with respect to the origin.

\section{HISTAMINE CHALLENGE}

Aerosols of normal saline, as a control, and doubling concentrations of histamine were administered for 30 seconds each by a Wright nebuliser, with $81 / \mathrm{min}$ airflow (nebuliser output $0.16 \mathrm{ml} / \mathrm{min}$ by weighing, aerosol aerodynamic mass median diameter $\left.1 \cdot 0-1 \cdot 5 \mu \mathrm{m}^{20}\right)$. The facemask, pneumotachograph removed, acted as a chamber into which the aerosol was directed over the mouth and nose of the sleeping infant. Beginning with $0.25 \mathrm{~g} / \mathrm{l}$, doubling concentrations of histamine were administered at five minute intervals until either a $30 \%$ decrease from baseline VmaxFRC had been observed or the maximum histamine concentration of $32 \mathrm{~g} / \mathrm{l}$ had been reached. Beginning one minute after completion of each nebulisation, six to 10 squeeze manoeuvres were then carried out. All technically satisfactory curves were analysed to give a mean $\dot{V} \operatorname{maxFRC}$ for each dose. As a safety measure, oxygen saturation $\left(\mathrm{SaO}_{2}\right)$ (Ohmeda Biox 3740 pulse oximeter), transcutaneous oxygen tension $\left(\mathrm{PtcO}_{2}\right)$ and carbon dioxide tension $\left(\mathrm{PtcCO}_{2}\right.$; Radiometer TCM3, Radiometer) were monitored continuously.

The provoking concentration of histamine producing a $30 \%$ decrease in $\mathrm{V} \operatorname{maxFRC}\left(\mathrm{PC}_{30}\right)$ from baseline was obtained by linear interpolation from dose-response plots of $\dot{V}$ maxFRC against $\log$ histamine concentration for each subject.

\section{ANALYSIS}

The lengths, weights, and ages of the infants with and without lower respiratory tract illness were compared using Student's $t$ tests. The gender distribution, ethnic origin, and history of maternal smoking in the two groups were compared using a $\chi^{2}$ test with Yates's correction. $\dot{V} \max F R C$ was adjusted to a length of $70 \mathrm{~cm}$ using regression equations derived from the normal subjects in the cohort. For normal male subjects, $\dot{V} \max F R C(\mathrm{ml} / \mathrm{s})=6.97$ (length in $\mathrm{cm}$ ) -244 , and for female subjects VmaxFRC $(\mathrm{ml} / \mathrm{s})=8.07$ (length in $\mathrm{cm})-270$. For female subjects length adjusted $\dot{V} \max F R C$ was further adjusted for gender from the regression equations (by multiplying by 0.822 ) to group male and female subjects together for comparison. The VंmaxFRC jacket pressure, and coefficient of variation data were skewed, and the $\mathrm{PC}_{30}$ data censored, so they were compared using the Mann-Whitney U test. Values were expressed as medians, with $95 \%$ confidence intervals $(\mathrm{CI})$ and interquartile ranges. The study design allowed a difference of two doubling concentrations in $\mathrm{PC}_{30}$ (boys and girls grouped together) and a $120 \mathrm{ml} / \mathrm{s}$ difference in length adjusted VmaxFRC (boys and girls compared separately) to be detected between the normal and symptomatic groups, with a power of greater than $80 \%$ at a significance level of $5 \%$.

\section{Results}

There were similar numbers of boys and girls in the study (23/22), but more boys than girls had developed symptoms by 6 months of age (13/10). Of those with lower respiratory tract illness, seven symptomatic boys and six symptomatic girls had coughed without any wheeze. Of the four boys and five girls from the original birth cohort of 54 infants who dropped out of the study, two boys and two girls had developed symptoms by 6 months. The ages and lengths of the infants with lower respiratory tract illness and control infants were similar, but the symptomatic male infants were significantly heavier than the normal boys $(p<0.05)$. There was no significant difference in the numbers of maternal smokers or non-white subjects between the two groups (table 1) or of other family members who smoked. Further analysis into the independent effect of parental smoking on lung function was precluded because of the small number of subjects.

Table 1 Baseline data. Mean (range) or number (\%) are given

\begin{tabular}{|c|c|c|c|c|c|c|}
\hline \multirow[t]{2}{*}{ Characteristic } & \multicolumn{3}{|l|}{ Boys } & \multicolumn{3}{|l|}{ Girls } \\
\hline & $\begin{array}{l}L R I^{*} \\
(n=13)\end{array}$ & $\begin{array}{l}\text { No } L R I^{*} \\
(n=10)\end{array}$ & $p$ Valuet & $\begin{array}{l}L R I^{*} \\
(n=10)\end{array}$ & $\begin{array}{l}\text { No LRI: } \\
(n=12)\end{array}$ & p Valuet \\
\hline $\begin{array}{l}\text { Age (months) } \\
\text { Weight }(\mathrm{kg}) \\
\text { Length }(\mathrm{cm}) \\
\text { Maternal smokers } \\
\text { Non-white subjects }\end{array}$ & $\begin{array}{l}6 \cdot 65(5 \cdot 5-8 \cdot 0) \\
8 \cdot 51(6 \cdot 92-10 \cdot 0) \\
69 \cdot 3(66-74) \\
4(31) \\
3(23)\end{array}$ & $\begin{array}{l}6 \cdot 45(6 \cdot 0-8 \cdot 0) \\
7 \cdot 74(6 \cdot 30-8 \cdot 74) \\
68 \cdot 5(63-72) \\
1(10) \\
1(10)\end{array}$ & $\begin{array}{l}0.52 \\
0.048 \\
0.43 \\
0.49 \\
0.79\end{array}$ & $\begin{array}{c}6 \cdot 60(6 \cdot 0-8 \cdot 0) \\
7 \cdot 73(5 \cdot 59-10 \cdot 0) \\
67 \cdot 8(63-70) \\
2(20) \\
2(20)\end{array}$ & $\begin{aligned} 6 \cdot 21(6 \cdot 0-7 \cdot 0) \\
7 \cdot 61(6 \cdot 6-10 \cdot 7) \\
67 \cdot 7(65-73) \\
1(8) \\
2(17)\end{aligned}$ & $\begin{array}{l}0 \cdot 10 \\
0 \cdot 80 \\
0 \cdot 90 \\
0 \cdot 70 \\
0 \cdot 83\end{array}$ \\
\hline
\end{tabular}

${ }^{*} \mathrm{LRI}=$ lower respiratory tract illness.

tp Value=significance of difference between subjects with LRI and without LRI ( $t$ test or $\chi^{2}$ test). 
Table 2 Gender and length adjusted $\dot{V} \operatorname{maxFRC}$ and $P_{30}$

\begin{tabular}{|c|c|c|c|}
\hline & $L R I^{*}$ & No $L R I^{*}$ & p Value \\
\hline \multicolumn{4}{|l|}{$\dot{\mathrm{V}} \max F R C(\mathrm{ml} / \mathrm{s})$} \\
\hline $\begin{array}{l}\text { No of subjects } \\
\text { Median } \\
95 \% \text { CI }\end{array}$ & $\begin{array}{l}23 \\
125 \cdot 4 \\
85 \cdot 0 \text { to } 164 \cdot 2\end{array}$ & $\begin{array}{l}22 \\
214 \cdot 9 \\
159 \cdot 4 \text { to } 298 \cdot 0\end{array}$ & 0.0001 \\
\hline$\underset{95 \% \mathrm{CI}}{\operatorname{Mean} \mathrm{CV}}(\%)$ & $\begin{array}{l}9.9 \\
8 \cdot 2 \text { to } 11 \cdot 3\end{array}$ & $\begin{array}{l}9 \cdot 0 \\
6 \cdot 1 \text { to } 9 \cdot 4\end{array}$ & $0 \cdot 11$ \\
\hline \multicolumn{4}{|l|}{$\mathrm{PC}_{30}(\mathrm{~g} / \mathrm{l})$} \\
\hline No of subjects & 19 & 20 & \\
\hline $\begin{array}{l}\text { Median value } \\
95 \% \mathrm{CI}\end{array}$ & $\begin{array}{l}10 \cdot 3 \\
2 \cdot 82 \text { to } 23 \cdot 82\end{array}$ & $\begin{array}{l}16 \cdot 5 \\
2.35 \text { to } 27 \cdot 86\end{array}$ & 0.97 \\
\hline
\end{tabular}

${ }^{*} \mathrm{LRI}=$ lower respiratory tract illness; $\mathrm{CV}=$ coefficient of variation (within subject).

For both male and female infants the length adjusted VंmaxFRC before challenge was significantly lower for the symptomatic group than for the control infants (table 2; fig 1). The median difference in length adjusted VmaxFRC between symptomatic and control infants was $108.0 \mathrm{ml} / \mathrm{s}$ for boys $(95 \% \mathrm{CI} 45.9$ to $251.6 \mathrm{ml} / \mathrm{s}$; $\mathrm{p}=0.006)$ and $102 \cdot 1 \mathrm{ml} / \mathrm{s}$ for girls $(95 \%$ CI $17 \cdot 8$ to $232 \cdot 2 \mathrm{ml} / \mathrm{s} ; \mathrm{p}=0.013$ ). There was no significant difference in repeatability of $\dot{V} \operatorname{maxFRC}$ expressed as a coefficient of variation between symptomatic and control subjects (table 2).

The median jacket pressure required to produce flow limitation during the squeeze manoeure was significantly lower for the group with lower respiratory tract illness than for the control infants (37 $v 46 \mathrm{~cm} \mathrm{H}_{2} \mathrm{O}$ respectively; $\mathrm{p}<0.05)$. There was no significant difference between symptomatic subjects and controls in the distribution of the shapes of the partial expiratory flow volume curves (concave:convex $=16: 7$ for subjects with lower respiratory tract illness and 12:10 for controls; $p=0 \cdot 46$ ).

Five infants awoke before completing the histamine challenge. During baseline measurements, one male infant from the group with lower respiratory tract illness had flow limited flow volume curves during tidal breathing, precluding histamine challenge. For the remaining infants, (nine control and 11 symptomatic boys; 12 control and seven symptomatic girls), there was no significant difference in $\mathrm{PC}_{30}$ between symptomatic infants and normal infants (table 2; figure 2). There was no correlation

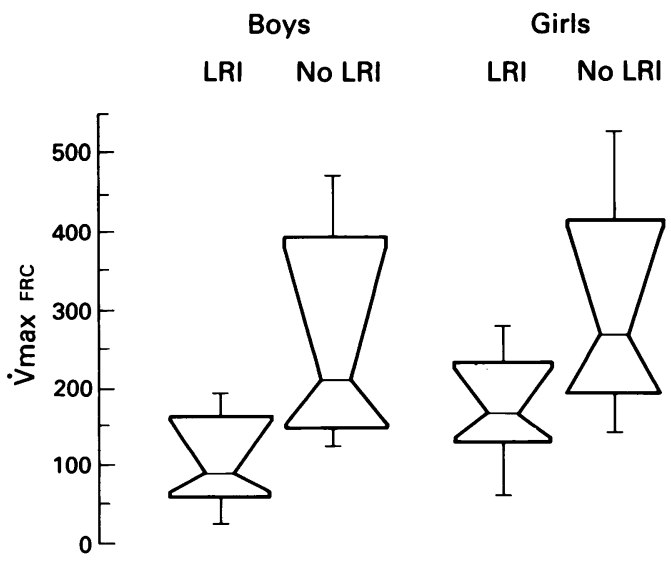

Figure 1 Maximum flow at functional residual capacity (VmaxFRC, ml/s), adjusted for length, for boys and girls with and without lower respiratory tract illness $(L R I)$. The box, notches, and bars indicate median with interquartile range, $95 \% C I$, and range respectively.

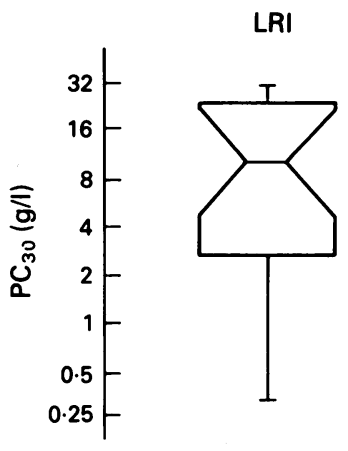

No LRI

Figure 2 Concentration of histamine which caused a $30 \%$ decrease in maximum flow at functional residual capacity $\left(P C_{30}\right)(g / l)$ for infants with and without lower respiratory tract illness $(L R I)$. The box, notches, and bars indicate median with interquartile range, $95 \% \mathrm{CI}$, and range respectively.

between length adjusted $\dot{V} \operatorname{maxFRC}$ before histamine challenge and $\mathrm{PC}_{30}$ for the whole study group.

Before histamine challenge, oxygen saturation was greater than $94 \%$ for all subjects. During bronchial challenge only four infants desaturated below $90 \%$, the minimum recorded $\mathrm{SaO}_{2}$ being $83 \%$, with spontaneous recovery. The maximum decrease in $\mathrm{Ptco}_{2}$ from prechallenge recordings was $4.2 \mathrm{kPa}$; in 11 infants $\mathrm{PtcO}_{2}$ decreased by more than $2 \mathrm{kPa}$ during challenge. There was no significant change in $\mathrm{PtcCO}_{2}$ during histamine challenge.

\section{Discussion}

In contrast with reports of an association between bronchial responsiveness and wheezing in older subjects, ${ }^{1-4}$ we found no association between bronchial responsiveness to histamine and lower respiratory tract illness in 6 month old infants. Baseline lung function, however, was reduced in symptomatic boys and girls, despite their being free of symptoms at the time of study. Our findings in children of atopic parents are similar to those reported by Stick $e t$ $a l$ in a random sample of the population, ${ }^{15}$ using similar methodology.

The baseline measurements of VंmaxFRC for the control subjects were similar to those few reference ranges reported for infants. ${ }^{21} 22$ All reference data show a wide scatter of size corrected VmaxFRC between subjects, but the method is repeatable within subjects. Doubt has been cast on the assumption that in healthy infants, flow limitation is achieved by the squeeze technique. ${ }^{23} 24$ This study does not determine whether the symptomatic infants had lower $\dot{V} \max F R C$ before any respiratory illness (that is, whether small airway calibre might have predisposed them to symptomatic lower respiratory tract illness ${ }^{25} 26$ ), or, alternatively, whether deterioration in previously normal lung function was a consequence of lower respiratory tract illness.

The configuration of the maximum expiratory flow-volume curve is a sensitive index of disturbed pulmonary mechanics, indicating imbalance between peripheral elastic and flow resistive components of the lungs. Minor changes have been interpreted as indicating 'small airway 
disease'. ${ }^{27}$ The similarity in the shape of the partial expiratory flow volume curves in the group with lower respiratory tract illness and control subjects, despite the lower $\dot{V} \max F R C$ in those with lower respiratory tract illness, is compatible with a pre-existing developmental pulmonary anomaly, as shown by Martinez and colleagues, ${ }^{25} 26$ rather than 'lung damage'. The configuration of partial expiratory flow-volume curves in infants are, however, at least partly dependent on the external compression applied. Excessive jacket pressures tend to produce increasingly convex curves and a consequent reduction in, VंmaxFRC, sometimes called 'negative pressure dependency of flow'. ${ }^{18}$ In our study various jacket pressures were used to determine the optimal pressure at which flow limitation was just achieved.

The squeeze technique does not take account of changes in the level at the end of expiration during bronchial challenge. Assessing bronchial responsiveness from changes in VmaxFRC may therefore result in an underestimate of response in infants whose functional residual capacity increases during challenge. ${ }^{28} \mathrm{~A}$ difference in the functional residual capacity in response to challenge, between infants with lower respiratory tract illness and controls, could have masked a true difference in $\mathrm{PC}_{30}$.

The levels of bronchial responsiveness to histamine which we found were lower (that is, $\mathrm{PC}_{30}$ was higher) than those reported previously. ${ }^{10} 12$ Differences between studies in the methodology, especially in the duration of histamine nebulisation and in the type of jet nebuliser used, may be the explanation. The effect of air entrainment on the dose of aerosol delivered to the lungs varies with age, ${ }^{29}$ but is unlikely to have been a factor as the infants in the group with lower respiratory tract illness and controls were of similar size and age.

Various factors may influence infant lung function and bronchial responsiveness. An Australian study looking at factors influencing bronchial responsiveness in early infancy showed that infants with either a family history of asthma or of parental smoking had increased levels of bronchial responsiveness at around 1 month of age. ${ }^{30}$ There was no difference in baseline VंmaxFRC. In contrast, a more extensive population survey in Boston (USA) showed reduced levels of forced expiratory flow within the first two months of life in infants born to smoking mothers, without a change in the functional residual capacity. ${ }^{31}$ They did not assess bronchial responsiveness. There were insufficient numbers of maternal smokers in our study to look at the effect of maternal smoking on baseline lung function or bronchial responsiveness. All of our infants had a parental history of atopy, though neither our subjects nor their parents were tested for atopy.

A prospective study in young adults ${ }^{32}$ showed that enhanced bronchial responsiveness usually precedes the development of clinical asthma and is compatible with a genetic basis for it. Epidemiological studies of 7 and 11 year old children have shown that wheeze is not associated with bronchial hyperresponsiveness in the absence of atopy, but is strongly related to bronchial hyperresponsiveness when atopy is present. ${ }^{33}$ In a large longitudinal study of 11 year old New Zealand schoolchildren, ${ }^{34}$ childhood asthma was shown to be strongly linked to allergy. Bronchial responsiveness correlated significantly with allergy as determined by the serum IgE concentration, even in some children with no clinical features of atopy.

There is reason to believe that the situation may be different in infants and young children, where infantile asthma is essentially a nonatopic illness ${ }^{35}$ even among the infants of atopic parents. ${ }^{36}$ At the age of 3 years there was no significant difference in bronchial responsiveness between atopic and non-atopic preschool children, all of whom had a history of severe wheeze. ${ }^{37}$ It has been suggested that only those wheezy infants who have an atopic predisposition and whose airways become sensitised to aeroallergens will develop asthma in later childhood. ${ }^{35}$ A prospective study of the relation between bronchial responsiveness and atopic sensitisation by inhaled allergens would further elucidate this hypothesis.

We suggest that at 6 months of age bronchial responsiveness is present in most infants and does not discriminate between those with and without lower respiratory tract illness. Lower respiratory tract symptoms are associated with reduced airway calibre rather than bronchial responsiveness. Later in childhood bronchial responsiveness may become a more important determinant of wheezing, together with atopy.

This work was supported by Action Research and the National Asthma Campaign. We are indebted to $\mathrm{Mr} \mathrm{R} \mathrm{H}$ Cumberland, Physiologic Ltd, for computer software and $\mathrm{Mr} \mathrm{N}$ Levy and $\mathrm{Mr}$ $\mathrm{N}$ Sen for technical assistance.

1 Cockcroft DW, Killian DN, Mellon JJA, Hargreave FE Bronchial reactivity to inhaled histamine: a method and clinical survey. Clin Allergy 1977;17:235-43.

2 Juniper EF, Frith PA, Hargreave FE. Airway responsiveness to histamine and methacholine: relationship to minimum treatment to control symptoms of asthma. Thorax 1981;36: treatment

3 Woolcock AJ, Peat JK, Salome CM, et al. Prevalence of bronchial responsiveness and asthma in a rural population. Thorax 1987;42:361-8.

4 Peat JK, Salome CM, Sedgewick CS, Kerrebijn J, Woolcock AJ. A prospective study of bronchial responsiveness and respiratory symptoms in a population of Australian schoolchildren. Clin Exp Allergy 1989;19:299-306.

5 Josephs LK, Gregg I, Mullee MA, Holgate ST. Non-specific bronchial reactivity and its relationship to the clinical expression of asthma. Am Rev Respir Dis 1989;140:350-7.

6 Josephs LK, Gregg I, Holgate ST. Does non-specific bronchial responsiveness indicate the severity of asthma? Eur Respir $\mathcal{f}$ 1990;3:220-7.

7 Pattemore PK, Asher MI, Harrison AC, Mitchell EA, Rea HH, Stewart AW. The interrelationship among bronchial hyperresponsiveness, the diagnosis of asthma and asthma hyperresponsiveness, the diagnosis of asthma and
symptoms. Am Rev Respir Dis 1990;142:549-54.

symptoms. Am Rev Respir Dis 1990;142:549-54.
8 Silverman M, Anderson SD. Standardisation of exercise tests in asthmatic children. Arch Dis Child 1972;47:882-9.

9 Wilson NM, Dixon C, Silverman M. Bronchial responsive ness to hyperventilation in children with asthma: response to ipratropium bromide. Thorax 1984;39:588-93.

10 Prendiville A, Green S, Silverman M. Bronchial responsiveness to histamine in wheezy infants. Thorax 1987;42:92-9.

11 Gutkowski P. Airway responsiveness following wheezy bronchitis in infants. Eur Respir $\mathcal{J}$ 1990;3:807-11.

12 LeSouef P, Geelhoed G, Turner DJ, Morgan SEG, Landau LI. Response of normal infants to inhaled histamine. Am Rev Respir Dis 1989;139:62-6.

13 Tepper RS. Airway reactivity in infants: a positive response to methacholine and metaproterenol. $\mathcal{f}$ Appl Physiol 1987; 62:1155-9.

14 Geller DE, Morgan WJ, Cota KA, Wright AL, Taussig LM Airway responsiveness to cold, dry air in normal infants. Airway responsiveness to cold,
Pediatr Pulmonol 1988;4:90-7.

15 Stick SM, Arnott J, Turner DJ, Young S, Landau LI, LeSouef PN. Bronchial responsiveness and lung function in recurrently wheezy infants. Am Rev Respir Dis 1991;144: in recurren.

16 Silverman M, Prendiville A, Green S. Partial expiratory flow volume curves in infancy: technical aspects. Bull Eur Physiopathol Respir 1986;22:257-62. 
17 Beardsmore CS, Godfrey S, Silverman M. Forced expiratory flow volume curves in infants and young children. Eur Respir 7 1989;2(suppl 4):154s-9s.

18 LeSouef PN, Hughes DM, Landau LI. The effect of compression pressure on forced expiratory flow in infants. pression pressure on forced expirt

19 Clarke JR, Silverman M. Partial expiratory flow volume curves. In: Dezateux CA, Fletcher ME, Rabette PS, Stanger LJ, Stocks J, eds. A manual of infant lung function testing. London. Institute of Child Health 1991.

20 Juniper EFJ, Cockcroft DW, Hargreave FE. Histamine and methacholine inhalation tests: tidal breathing method. Laboratory procedure and standardisation. Canadian Thoracic Society. Lund: DRACO, 1991

21 Tepper RS, Morgan WJ, Cota K, Wright AL, Taussig LM, GHMA paediatricians. Physiologic growth and development of the lung during the first year of life. Am Rev Respir Dis 1986;134:513-9.

22 Hanrahan JP, Tager IB, Castile RG, Segal MR, Weiss ST, Speizer FE. Pulmonary function measures in healthy infants-variability and size correction. Am Rev Respir Dis 1990;141:1127-35.

23 Anonymous. Infant pulmonary function testing workshop I; 1990 May; Boston, USA. [Conference report.] Pediatr 1990 May; Boston, USA.

24 Anonymous. Infant Pulmonary Function Testing Workshop II; 1990 September; London. [Conference report.] Pediatr Pulmonol 1991;10:219-22.

25 Martinez FD, Morgan WJ, Wright AL, Holberg CJ, Taussig LM, GHMA paediatricians. Diminished lung function as a predisposing factor for wheezing respiratory illness in infants. N Englf Med 1988;319:1112-7.

26 Martinez FD, Morgan WJ, Wright AL, Holberg C, Taussig LM, GHMA paediatricians. Initial airway function is a risk factor for recurrent wheezing respiratory illnesses during the first three years of life. Am Rev Respir Dis 1991;143: 312-6.
27 Hyatt RE, Rodarte JR, Mead J, Wilson TA. Changes in lung mechanics: flow-volume relations. In: Macklem PL, Permutt S, eds. Lung biology in health and disease. The lung in the transition between health and disease. Vol. 12. New in the transition between health

28 Clarke JR, Reese A, Silverman M. Changes in FRC during histamine challenge in infants. Am Rev Respir Dis 1991; 143:A24.

29 Stick SM, Turnbull S, Chua HL, Landau LI, LeSouef PN. Bronchial responsiveness to histamine in infants and older children. Am Rev Respir Dis 1990;142:1143-6.

30 Young S, LeSouef PN, Geelhoed GC, Stick SM, Turner KJ, Landau LI. The influence of a family history of asthma and parental smoking on airway responsiveness in early infancy. NEnglf Med 1991;324:1168-73.

31 Hanrahan JP, Tager IB, Segal MR, et al. The effect of maternal smoking during pregnancy on early infant lung function. Am Rev Respir Dis 1992;145:1129-35

32 Hopp RJ, Townley RG, Biven RE, Bewtra AK, Nair NM The presence of airway reactivity before the development of The presence of airway reactivity before
asthma. Am Rev Resp Dis 1990;141:2-8.

33 Clifford RD, Howell JB, Radford M, Holgate ST. Associations between respiratory symptoms, bronchial response to
methacholine, and atopy in two age groups of schoolmethacholine, and atopy in two age grou
children. Arch Dis Child 1989;64:1133-9.

34 Sears MR, Burrows B, Flannery EM, Herbison GP, Hewitt CJ, Holdaway MD. Relation between airway responsiveness and serum IgE in children with asthma and in apparently normal children. $N$ Engl f Med 1991;325:1067-71.

35 Wilson NM. Wheezy bronchitis revisited. Arch Dis Child 1989;64:1191-9.

36 Sporik R, Holgate ST, Cogswell JJ. Natural history of asthma in childhood-a birth cohort study. Arch Dis Child 1991, 66:1050-3.

37 Wilson NM, Phagoo SB, Silverman M. Atropy, bronchial responsiveness and symptoms in wheezy 3 year olds. Arch Dis Child 1992;67:491-5. 